\title{
ASSESSING THE ALIGODON RIVER AND ITS WATERSHED AS DRINKING WATER SOURCE
}

\author{
Alexander L Ido ${ }^{1}$ \\ ${ }^{1}$ Assistant Professor, Institute of Engineering and Technology, MOSCAT, Philippines
}

\begin{abstract}
With increasing scarcity of drinking water, the need for a sustainable source of water for drinking has been among the concerns of many communities of the world. This study aims to assess the viability of Aligodon River, and its watershed to be used as raw water source of the municipality of Claveria, Misamis Oriental, Philippines. It mainly determines the existing land use of the watershed and characterizes the Aligodon river body to ensure the feasibility of giving the water demand of the would-be concessionaires of the treated raw water. The ArcWindow software is used in delineating the boundaries of the watershed. Area and location of the basin are determined using GPS method. Characterization of the river body is determined according to water flow and essential physical characteristics. The result of the investigation revealed a forested watershed of Aligodon river with no human habitation, an indication of no domestic waste contamination. Water flow is significantly affected by the season of the year. Nonetheless, even during the dry season, the water flow can sufficiently supply the water demand of the target community to be served by the water system.
\end{abstract}

Keywords: Watershed Assessment, Drinking Water Source, Water Flow, River Assessment

\section{INTRODUCTION}

Water is considered as the most important substance for the existence of all living organisms. It is used to build tissues of both plants and animals at all stages of growth and development. For human beings, almost all of their endeavors are always associated with water for without it; life could not exist.

One of the problems related to water nowadays is the source of safe and reliable potable water. Many suffered problems on the scarcity and poor quality of water in their respective communities. The establishment of their communities is significantly influenced by the availability of clean water.

One of the communities that suffer water shortage is Claveria, Philippines. This problem is prevalent especially in those areas situated on the plateau where most of its water drains to the lower ground. The hinterland communities of Lanise, Luna, Tamboboan, Ane-i and Patrocinio of Claveria are known to have no adequate drinking water. As cited in the situational analysis of the Municipality of Claveria [1], only $23.84 \%$ households of the said communities have a water supply on piped waterworks level 2 (communal) while $58.62 \%$ of families get water from the spring or river. The other $7.74 \%$ and $9.79 \%$ of households have been getting water from an open shallow dug well and an artesian well, respectively.

Due to limited water supply, most of the residents of the said communities were practically without water when the dry spell extended during summer time. This time is the worst time of the year experienced by the residents whereby they need to travel some distance away to fetch water.
The result in the recent situational analysis implies that problem on the accessibility of water from spring or river is at hand. Further, the growing demand coupled with the fluctuating flow of water aggravates the issue on water scarcity. Besides, the quality of water of those springs and rivers which $58.62 \%$ of households of the five communities are not yet tested.

Amidst this problem of water shortage in Claveria, there are communities of this municipality that are abundantly endowed with a potential potable water source. Mat-i is one community with abundant water sources such as rivers, creeks, and springs that can potentially be used as a clean water source.

In answering the growing demand for potable water, the local government of Claveria prioritizes the water system project to convey and treat water into the needing communities. The Aligodon river of Mat-i is identified as potential source of the new water system.

This study assessed the viability of the Aligodon river and its watershed to prove the likeness of tapping the river as a source of the water system. Further, this study determined the existing land use of the watershed and characterized the water of the river.

\section{MATERIALS AND METHODS}

\subsection{Establishment of Sampling Stations}

Two (2) sampling stations were established in the study area. The first station (lower station) was about 10 meters above the diversion site of the water system. The vegetations along the riverbank of 20 meters radius are few banana and chayote plants, after which are forest areas in hilly lands on both sides of the river. The second station 
(upper station) was approximately 250 meters from the first station. This second station was the headwater right after an unnamed stream tributary that met the Aligodon River main channel.

\subsection{Collection of Data}

The water flow of the river was determined by float method adopted by Waterwatch Philippines [2].

\subsection{Water Demand and Land Use Determination}

The water demand was calculated based on the total population of the five target recipient communities of the water system. In projecting water demand, a design period of 50 years by Muring [3] was applied. A Philippine data on the average per capita usage of the rural area level III connection which is 60 liters per capita per day was also used in the projection [3]. Further, the projection of population and water demand are calculated using the population growth rate of Claveria, Misamis Oriental of $1.12 \%[4]$.

Estimate of population and water demand (WD) were computed based on Field Manual for Design of Rural Gravity-Flow Water System [3] as shown in Eqs [1-4]. The year is the design period of 50 years.

Water demand $\left(\frac{l}{d}\right)=\frac{\text { total population } \times 60 L / \text { pax }}{24 \text { h per day }}$

Water demand $\left(\frac{m^{3}}{s}\right)=6.944 \times 10^{-7}$ total population

Pop' $n$ Growth Rate Factor $(F)=(1+$ growth rate $) *$ years

Projected Population $=F *$ current population

Site survey determined the land use and condition of the Aligodon watershed. An expert on the GPS mapping from World Agroforestry Center-International Center for Research in Agroforestry (WAC-ICRAF) based in Claveria, Misamis Oriental was requested to accompany the researcher in getting the waypoints of the watershed. The waypoints were then plotted in the ArcWindow program. The Aligodon watershed was delineated using the plotted points in the ArcWindow, digitized topographic map, and digitized land use map. It was determined by tracing the highest contours surrounding the Aligodon river based on the digitized topographic map.

\section{RESULTS AND DISCUSSION}

\subsection{Existing Land Use of Aligodon Watershed}

Aligodon River is located in between two mountains ranges. The built up area, river stream, and community of Mat-i with human settlement, is located at the downstream of the river. Aligodon River, where diversion structure will be constructed, is located at approximately 1000 meters above mean sea level and about $2 \mathrm{~km}$ upland from the nearest downhill residence area.
Figure 1 shows the points plotted in Google Earth Map using the data gathered through GPS. Plotted in the figure are global positions of the sampling station, river water streamline and the Mat-i community built up area (residential). Emphasized in the illustration is the watershed of Aligodon river above the sampling area.

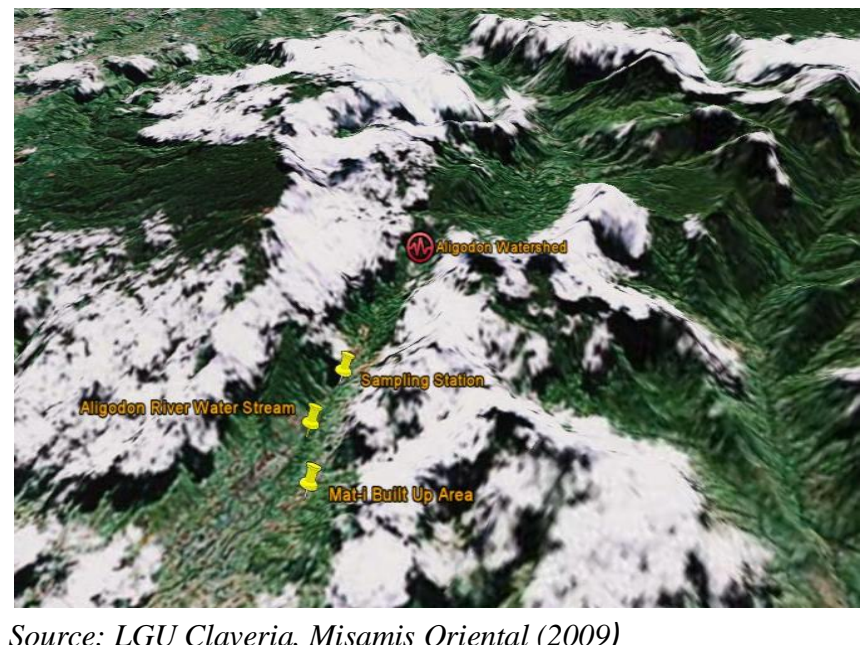

Figure 1. Terrain of the Aligodon Watershed

Based on the terrain of the area, it is apparently indicated that the watershed of Aligodon river is a forest area. No human settlement is observed in the area due to steep slopes. Besides, this watershed is declared as protected area for it is within the Mount Balatukan Nature Park which prohibits habitation of the human being. This result is supported by the study conducted by the Local Government Unit (LGU) of Claveria (2009) through Participatory Land Use Appraisal (PALA) revealing that more than $50 \%$ of the land use of Mat-i area is considered forest land with broad-leaved trees growing in the spot.

The study revealed the same result of the investigation of LGU of Claveria (2009) which clearly pointed out that the sampling station, where the water samples were taken, is located in the secondary forest. Surrounding upland such secondary forest is primary forest. This observation is best illustrated in Figure 2.

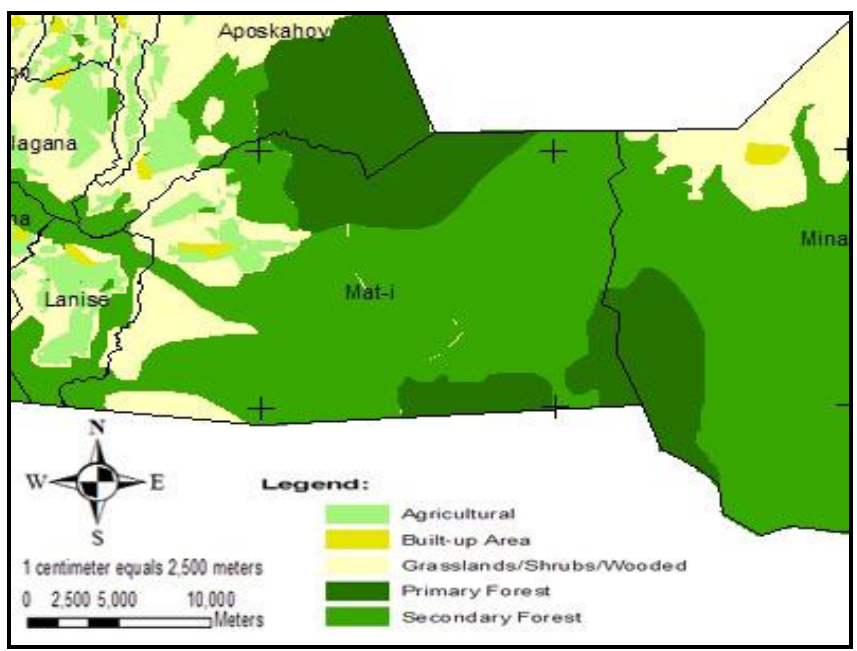

Figure 2. Land Use Map of Mat-i and Nearby Communities 
Figure 2 illustrates the sampling station located in the secondary forest. The north and upland portion of the area is dominated by primary forest while secondary forest dominated the southern and lower part.

The sampling location immediately above the diversion area of the water system is still accessible by humans. Upland of the sampling station is declared as a protected area. Through ocular inspection, it was observed that there were few trunks of growing bananas and few hills of chayote plants planted within the riparian zone of the area. However, was left unattended with minimum to zero tillage being practiced. Though there is a trail that people used in harvesting and in hunting wildlife for food, it gave no trace of regular cultivation. The result implied that the watershed of the Aligodon River is practically a forested area with minimum intervention of human activities.

Using ArcWindow software, digitized topographic map, and land use map; Aligodon's immediate watershed was delineated by tracing the highest contours surrounding the Aligodon River. Figure 3 illustrated the land area covered by the direct watershed of the source of the water system in Aligodon River and the corresponding land use.

Based on the delineation of the Aligodon watershed, it was found out that the watershed has a total land area of 435.83 hectares. It is also revealed that almost $50 \%$ of the land area, upland, and north of the watershed, is considered primary forest. While the remaining more than $50 \%$ of the land area, south of the watershed, is found to be a secondary forest.

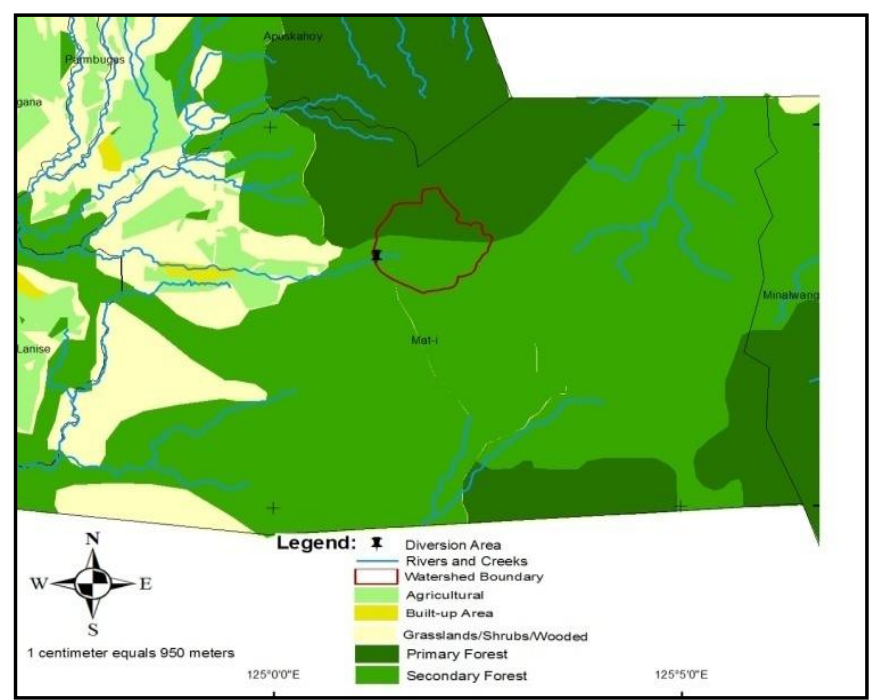

Figure 3. Immediate Aligodon Watershed Boundary of the Source of Water System and its Land Use

Figure 4 shows the detailed delineated watershed of Mat-i. It is established by LGU of Claveria (2009) that Aligodon River watershed is a sub-watershed of the well known Cabulig River. This Cabulig River is a main channel 40kilometer river that passes through the center of Jasaan, finally draining itself in Bobuntugan, Jasaan, Misamis Oriental to Macajalar Bay.

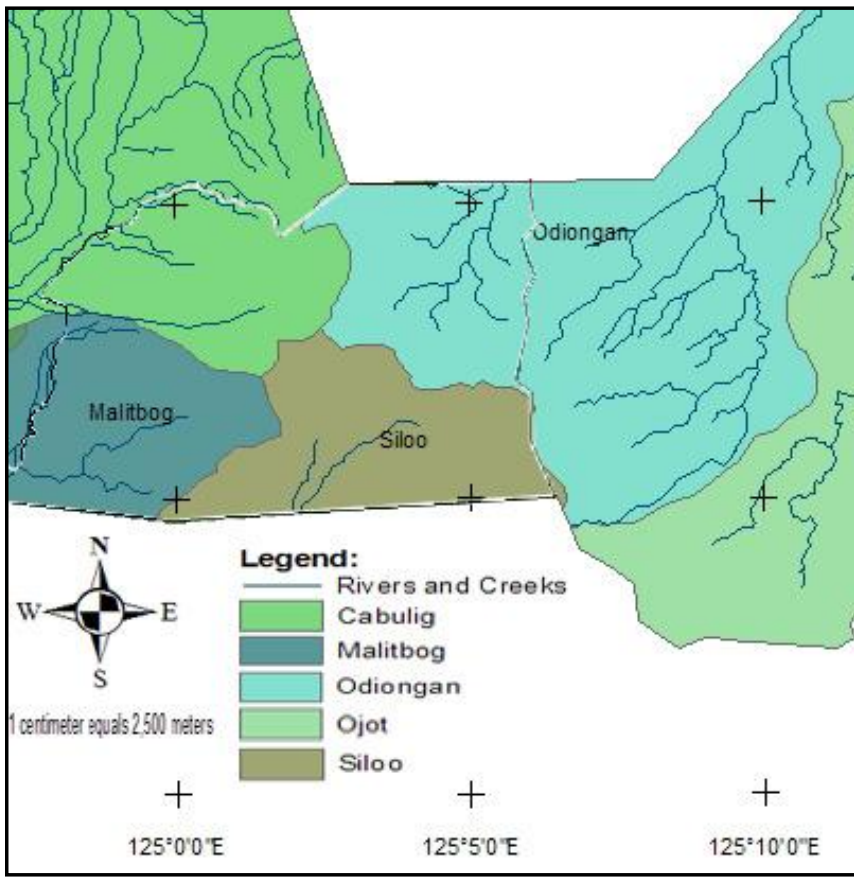

Figure 4. Watershed Map of Mat-i and Nearby Communities

\subsection{Water Flow of Aligodon River}

Table 1 shows the wet season average water flow of 1.9567 $\mathrm{m}^{3} / \mathrm{s}$ while $0.7893 \mathrm{~m}^{3} / \mathrm{s}$ during the dry season. The result suggests that the $0.7893 \mathrm{~m}^{3} / \mathrm{s}$ water flow during the dry season, when water is more needed by the consumers, will become the basis of the amount of water that will be diverted to the water system. The amount of water that will be applied for the permit to the National Water Resources Board for diversion to the water system should not exceed $0.7893 \mathrm{~m}^{3} / \mathrm{s}$ [5]. According to Municipal Engineer of Claveria, the Water System applied $0.280 \mathrm{~m}^{3} / \mathrm{s}$ diversion flow rate from NWRB. The $0.280 \mathrm{~m}^{3} / \mathrm{s}$ is about $35.47 \%$ of the $0.7893 \mathrm{~m}^{3} / \mathrm{s}$ water flow that will be diverted during the dry season.

Table 1. Water Flow of Aligodon River during Wet and Dry Seasons

\begin{tabular}{lcc}
\hline \multirow{2}{*}{ Physical Property } & \multicolumn{2}{c}{ Mean Value } \\
\cline { 2 - 3 } & Wet Season & Dry Season \\
\hline Water Flow, $\mathrm{m}^{3} / \mathrm{s}$ & 1.9567 & 0.7893 \\
\hline
\end{tabular}

The water flow is directly related to the rainfall pattern of the area. Based on the history of rain from June 1997 to December 2009, it was revealed that dry season of Claveria happened during the first four months of the year. Based on the record, a gradual decreased of rainfall is experienced from January to April with recorded lowest mean monthly rainfall of 108.70 millimeters in April. It postulated that approximately $35 \%$ of the Aligodon River water during the dry season would be diverted to the Claveria Water System. This shortage is expected to happen during the months of January to April when dry season occurs. 


\subsection{Water Demand of Would-be Concessionaires}

The water demand is computed based on the total population of the five (5) communities namely Lanise, Luna, Tamboboan, Ane-i, and Patrocinio. These communities are the identified consumers of the water system of Claveria from the Aligodon River water source. The population of such communities is $25.36 \%$ of the total population of the 24 communities of Claveria.

Figure 5 shows the projected water demand in 50 years time of five (5) communities of Claveria. It is apparent that the water demand of the expected concessionaires is way below the water flow rate of the river during the dry season.

The actual demand in the current year 2009 of $0.00824 \mathrm{~m}^{3} / \mathrm{s}$ is small when compared to the water flow of $0.7893 \mathrm{~m}^{3} / \mathrm{s}$ during the dry season. This value means that the river water can sufficiently provide the water requirement needed in the water system even during dry season assuming that the river's flow rate will not change in the next 50 years. The rainfall pattern, which can be related to the water flow of the river, is also observed to have an almost constant average rainfall from 1997 to 2009 of Claveria [6]. The ten-year rainfall observation, therefore, indicates that variations in rainfall will not significantly affect the water flow and the water demand in the next 50 years.

This result implies that the amount of rainfall that will flow back to the river in a year either in the form of run-off, soil flow or base flow is expected to be the same for the next 50 years when the surrounding watershed will be maintained.

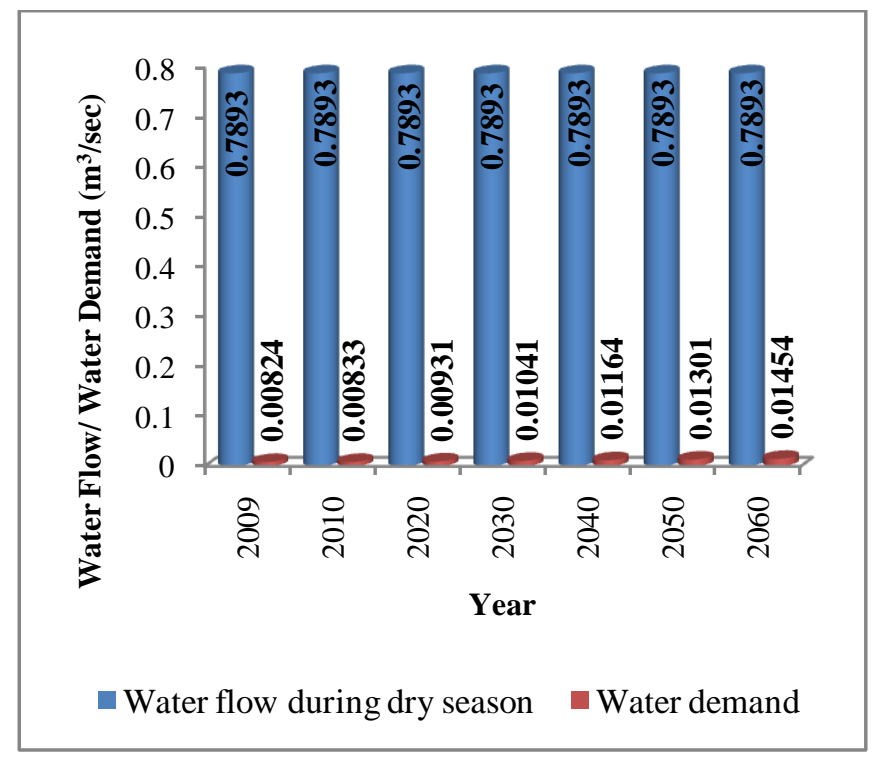

Figure 5. Comparison of the Water Flow and Water Demand of Target Communities for 50 Years Operation [Assumption: No changes in the water flow in the next 50 years]

As projected, the water demand increases considerably every ten years. Assuming that the water flow of the river will not significantly change in the next 50 years and that the growth rate will be constant, the projected water demand equivalent to $0.01454 \mathrm{~m}^{3} / \mathrm{s}$ in the year 2060 will be lower compared to the water flow during the dry season.
This water demand of $0.01454 \mathrm{~m}^{3} / \mathrm{s}$ in the year 2060 is only $1.84 \%$ of the total water flow during the dry season. Also, this water demand of $0.01454 \mathrm{~m}^{3} / \mathrm{s}$ is just $5.20 \%$ of the 0.28 $\mathrm{m}^{3} / \mathrm{s}$ diversion flow rate as applied from NWRB. The budget for the construction of the water system is likewise designed for $0.28 \mathrm{~m}^{3} / \mathrm{s}$. This result implied that future expansion of the water system is feasible to serve new communities as concessionaires. The remaining $94.8 \%$ of the design diversion flow rate could be used for new concessionaires of the water system within the municipality or even in nearby municipalities.

The assumption that the water flow will not change in the next 50 years is based on the laid out Sustainable Plan of the LGU of Claveria for a sustainable water system in the next 50 years. Buffer zone of one-kilometer radius from the diversion area will strictly be protected through LGU management. With this, the water system would continue to be beneficial to the served community in an ideal design life of GI pipes of 50 years. The Aligodon river, would then sufficiently address the water demand of the five communities in the next 50 years of operation.

\section{CONCLUSIONS}

The immediate watershed is found healthy as implied in its sound characteristics. The water flow could sufficiently supply the needed volume of water in the would-be concessionaires even during short duration drought. The water demand of the projected population after 50 years is less when compared to the existing water flow of the river even during dry season.

Overall, the study proved that the Aligodon River is a splendid source of potable drinking water of Claveria. Its quantity and quality of watershed are ideal to answer the need of the drinking water of the highland communities of Claveria. The result is a strong groundwork to support the plan of the local government to put up new water system for the five communities.

\section{ACKNOWLEDGMENT}

The author would like to acknowledge the financial support of the Faculty Development Program of the Philippine Commission on Higher Education (CHED) and the technical help of Engr.Ma. Isabel Dumlao and Dr. Renato O. Arazo.

\section{REFERENCES}

[1] Situational Analysis of the Municipality of Claveria.2009.

[2] Environment Australia. Waterwatch Australia Steering Committee. Retrieved February 27, 2010 from http://www.hort.wisc.edu/cran/pubs archive/newsletters/2003/news 200307 05.html.

[3] Muring, Petronio C. (compiler). Field Manual for Design of Rural Gravity-Flow Water System. 1994

[4] Commission on Population-Regional Population Office No. 10. Retrieved February 27, 2010 from 
http://www.popcom.gov.ph/regions/10/

Misamis\%20Oriental\%20 Profile.htm (2000)

[5] Alikpala, R. "Philippine Country Water Highlights". National Water Resources Board. December 2006.

[6] Weather Data. MOSCAT Agromet Station. Claveria, Misamis Oriental, Philippines. 2010.

\section{BIOGRAPHY}

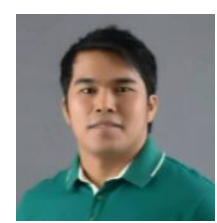

Engr Alexander L. Ido is an Assistant Professor of the Institute of Engineering and Technology of MOSCAT. He was a visiting scholar at Texas A\&M University, Texas, USA. 